\title{
THE CULTURAL PRACTICE OF LOCALISING MEDIATED SPORTS MUSIC
}

The crowd gathers. Hellos with friends and familiar faces are exchanged before I make my way to my familiar seat. The latest news is discussed with those sitting next to me: who is injured, who is going to win the game for us, and do we have a good referee today? Someone is munching on a grilled sausage; another is saving it for half time. A third sips his coffee while children happily eat their ice cream. The friend to my left wears long johns in July, the friend to my right usually arrives late carrying his lunch, a plate of kebab. A popular song plays in the background, flags are waving in the wind, and the sun shines over the local sporting event. Suddenly, a march blares from the PA system and in the blink of an eye the focus of the crowd shifts towards the pitch. The crowd claps along to the instrumental German military march Alte Kameraden while the home and away teams walk on to the pitch. The supporter group announces its presence by bursting into one of their familiar chants. It's game time in Jakobstad/Pietarsaari.

The above example describes my personal routine of going to an $\mathrm{FF}^{\mathrm{FarO}}{ }^{1}$ football game at Keskuskenttä in Pietarsaari, Finland. This routine is repeated nearly once a week during football season, only the weather differs from game to game. From a cultural and musicological standpoint, what is interesting about this scenario is the fact that a German instrumental military march, written by

I From now on simply Jaro. "FF" stands for "fotbollsföreningen" while "JS" is the Finnish equivalent, "jalkapalloseura." Both abbreviations can be translated as Football Association. 
Carl Teike in 1889 , is embedded into this everyday routine of watching football with my friends.

During the $2 \mathrm{O}^{\text {th }}$ century both sports and music became increasingly mediated experiences. At sporting events the playing of LP's has been supplanted by digital sources; since late 1960 s teams have had the possibility to record their own songs; and in the $21^{\text {st }}$ century, thanks to new production and distribution technologies, practically anyone can record a song for his or her local team.

In most cases the music is not necessary for the execution of the sport, meaning that we listen to the music as a part of the total experience, or as the example above illustrated, as a member of a local sporting community. Although the largest teams today are more like transnational enterprises, they are often understood to represent some form of locality (local origins, city, village, stadium) and their community of fans relate themselves to this locality. According to sports geographer John Bale (2000: 91), a community of fans is a social network of interacting individuals, although it is not necessary for the community to be concentrated in a defined territory.

This tension between the local and the global makes the question of local and community belonging particularly interesting, and from an ethnomusicological point of view, what part music plays in this process. My perspective is influenced by the central ethnomusicological idea of viewing music as culture, which ultimately implies studying musical practices as well. The urge to focus on different aspects of engaging with "the media", as in the mediation of music, as opposed to just focusing on chanting, is a strategy to better understand "what's going on" in the media saturated context of experiencing sporting events.

The aim of this article is to examine how local and community belonging are constructed through musical mediation processes. Music is mediated through electronic recording and media dissemination. On the other hand, media disseminated music can also become a part of local cultural practices and communities can ascribe local meanings to it. At a later stage, such localised music, so to speak, can be mediated again and spread in new geographical and cultural milieus.

What makes these processes particularly relevant is the development of digital media, which influences the production, distribution, and consumption of music. I have chosen to divide these processes into four major themes, which 
also form the disposition of this article. The starting point for my thinking are ethnomusicologists Dan Lundberg, Krister Malm, and Owe Ronström (Lundberg et al. 2003: 70) who, drawing on media researcher Roger Wallis and Krister Malm (Wallis \& Malm 1984), state that since the end of the 1980 os it is possible to identify four main types of "mediational and mediaizational processes." These four types have been named primary mediaization, mediaizational reworking, demediaization, and remediaization and they are used to describe the different processes involved in the intersections between musical traditions, mediation, the local, and the global. The concepts are used to illustrate how media logic affects music production.

In recent years, adapting to media logic has in media studies been connected with the concept of mediatization, which is a concept used to understand "longterm cultural and social change following ongoing mediated communication" (Lundby 2014, 7). In music research, especially popular music research, the role of the media (as a part of "the music industry") and its influence (on the commercialization and distribution of music) has been widely recognized. Therefore I acknowledge here that music, as well as sport and society as a whole, are affected by the media in many ways. With this said, I consider the concept of mediatization an umbrella term. Building on Lundberg et al.'s (2003) mediaization theories (mediaization without the " $\mathrm{t}$ "), which derive from an ethnomusicological tradition, is a strive to complement the discussions of "media's embedding in everyday life" (Couldry \& Hepp, 2013: 195) at a lower level of abstraction, here conceptualised as four different themes.

The first theme I will discuss is how music is created for distribution within a local sporting community, a process I call the primary localisation of mediated sports music. Despite the fact that the music is mediated, as in recorded, it is not affected by a strong mediaization process that strips it of its local characteristics. Even though the team might be a transnational enterprise the songs are not affected by globally mediated genre expectations and mediaized for primary distribution outside community of fans. On the contrary, local characteristics, those related to the team and the local community, are of the utmost significance, since they are relevant for the construction of an imagined "us". What Lundberg et al. (2003: 70) call primary mediaization involves a process that affects music and modifies it to be suitable for a non-local audience. This is not the case with local 
fight songs, which are produced for a primarily local audience with a connection to the team.

The second theme concerns the (re)localisation of music into a new sporting context. This process does not include removing the music from the medium or reworking the music. The key point in this localisation process is that new meanings from the sporting context are assigned to the music. This means that music spread through media, written for other purposes, when used by teams and supporter communities can over time gain new local meanings and become representative symbols of the team.

As a third theme I will illustrate how mediaized music, songs written for other purposes and spread through media, have been adapted by teams or supporter communities by rearranging them and providing new, localised lyrics. The core of this process is a demediaization process, meaning that the music is removed from the medium by supporters who take control over the music and rework the content to be performed in a new context. Even though crowd chanting in general is perceived as an oral, face-to-face tradition, it is a culture influenced and supported by mediation technology.

Finally, pieces of music that have been localised into a new context can be subject to a remediaization process, meaning that the song is mediated again in a reworked format. This process can include the song being rearranged with new lyrics or as a mashup. The remediaization uncovers and depicts the importance of certain songs in the community since it includes the possibility of interpreting, reflecting, and expressing localised symbols and meanings. The fourth theme addresses the possibility to mediaizationally rework music at a local level, something primarily possible only in the studios of large media companies (Lundberg et al 2003: 71). Due to the democratization of music production and distribution, fans can now make tributes to their favourite teams or players and upload them to the Internet. This means that, to a certain degree, mass media logic can be bypassed, through what is called a DIY attitude, meaning avoiding intermediation from commercial forces in the production process. In this way, music production and distribution have in part been affected by a democratization process ${ }^{2}$. I see this as also being linked to law professor Lawrence Lessig's (2008) thoughts on what he refers to as "Read/Only culture" (RO) and "Read/Write culture" (RW). 
These four themes shape the outline of my analysis and serve as a way to categorize my material. As an (ethno)musicologist doing fieldwork at sporting events, the theories of Lundberg et al. (2003) and Wallis and Malm (1984) are inspiring starting points, since studying the soundscape and the music culture surrounding a specific team can be just as inspiring as analysing music culture in a foreign country. Both objects also exist in the tension of the construction of local and global. Ethnomusicologists have traditionally travelled around the world to study pristine local music that is presumably unaffected by the global music industry. I am not proposing that every local sporting team has its own traditional or pristine form of music tradition, but as I will demonstrate later, many teams and their communities of fans have their own distinctive songs and cultural practises of using mediaized music.

The field of combining music and sports is a field that is very much affected by the "global," namely music, disseminated through various media. But, the unique music written for the local team, though being mediated (that is, recorded), has not been mediaized to meet the standards of global, transnational distribution. While I am aware of the problems inherent in the term global (see for example Turino 2003 or Stokes 2007), I refer to global as music distributed by the international music industry which include mediaization, a process dissimilar to making music available "globally" via various platforms on the Internet.

The material for this article is the result of fieldwork conducted during Finnish male sporting events, particularly the games of football team Jaro, pesäpallo ("Finnish baseball") team Vimpelin Veto, and ice hockey teams HC TPS and HIFK, all taking place within 2012-2015. As part of my fieldwork I have also conducted interviews with DJs and key individuals in different sporting organisations and made use of secondary material, for example, newspaper articles, recordings, and videos. The field observations have been analysed from different perspectives in Ahlsved (2013) and Ahlsved (2014), both parts of my doctoral dissertation on the use of recorded music during sporting events.

In this article I also use material collected for a fieldwork project (2014-2015) documenting the tradition of using military marches as entrance music at football games in Ostrobothnia, Finland (see Ahlsved 2015). This archival project was conducted with economic support from The Institute of Finland-Swedish Traditional Music and the material is stored in their archive in Vaasa (FMI 445). Teams in- 
volved in this project were Jaro (Pietarsaari), Jakobstads Bollklubb (Pietarsaari), Kokkolan Pallo-veikot (Kokkola), Gamlakarleby Bollklubb (Kokkola), and Vasa IFK (Vaasa). Field recordings (video and sound) were complimented and contextualized by interviewing people with historical insights into these teams.

The material for this article is diverse, and intentionally not limited to a case study concerning one single team and one particular sport. By using observations from several sports, I wish to nuance the view of the intersection between music and sport, a field dominated by studying football (soccer) culture. The findings are presented as four themes; a result of the material at hand being put into a larger context and analyzed within a theoretical framework concerning the mediation and mediaization of music.

\section{The primary localisation of music in a sporting community}

Most professional teams have their own songs, which usually are produced by local musicians. Although the songs are mediated, as in recorded, they are not affected by a strong mediaization process. On the contrary, local characteristics related to the team and the local community, are inevitable in the process of primarily localising music in a sporting community. I do not here refer to local musical styles as much as representative words and phrases. What Lundberg et al. (2003: 70) calls primary mediaization involves a process that affects music and modifies it to be suitable for a non-local audience. This is not the case with local fight songs, which are produced for a primarily local audience with a connection to the team.

The songs are not confined by globally mediated genre expectations (see Negus 1999: 28-29) but there are still structural requirements for the songs to "work" in the local sporting community, for example, unison melodies or other elements that elicit crowd participation; tempo; and repetition of identifiable local symbols such as names, places and the colours of the team. The songs are not primarily targeted at a national or global audience outside of the community of fans. These team related songs are therefore most likely to be heard only at games or fan gatherings. But since they are mediated they are often also uploaded to platforms that make them accessible to fans. 
From the study of a few locally significant songs it is possible to distil three main categories or rules that the songs often confine to. That is: 1) using the name of the team and its symbols in the song; 2) referencing places or spaces linked to the team and its role as a representative of the local community (in the bilingual area of Ostrobothnia this is visible in the ideology behind selecting the song's language); and finally 3) the songs include structural elements that elicit crowd response and participation, for example repeating the team's name as hooks.

An example of two songs mediaized only to be spread inside the local football community are the songs Go Jaro go (FF Jaro 2013) and Jeppis dynamite (see Josef Krokvik 2010), both originally written for Jaro from Pietarsaari, Finland. Both are written by local musicians and include elements, especially lyrical, that make them representative for not only the football team but also for the city and region that the team represents in its very name.

The men behind Go Jaro go are Kjell Strömsholm and the ex-player, coach, and manager Jan-Eric "Janken" Holmberg. The song was recorded around 1995 by a band called Pampas, in which Strömsholm was vocalist. "Pampas" is a popular reference to the very flat Ostrobothnia region. The song is in a 1950s-1960s bluesy form while the drums are reminiscent of Chubby Checker's rock ' $n$ ' roll classic Let's twist again [1961]. The song has three chords and a refrain where the words "go go Jaro go go" are repeated after every two bar phrase.

Sociologist Dan Porsfelt, who has studied Swedish "supporter rock" bands, mentions that common themes in the lyrics of particularly one of the bands he has studied, is the love of the club and its symbols (Porsfelt 2009: 198). Another feature is topophilia, as in love of place, but not just as merely geographical place, but following Yi-Fu Tuan's (1974: 113) concept of topophilia as "human being's affective ties with the material environment". In football culture this is often linked to the affective relationships with the team's home stadium, with quasi-religious connotations or referring to it as "home" (See Bale 1993: 64-93). In Go Jaro go the team is obviously the object of affection, since the hook of the song is the repetition of the team's name, but the most geographically significant identity marker is that the song has verses in three different languages; Swedish, Finnish, and English. The songs multilingual character reflects Jaro's role in the local community. According to local sports journalists Bäck and Sundqvist (2002: 9-10), Jaro is the one thing that has transcended and united language and class 
formations in Pietarsaari. Since the team's founding in $1965^{3}$ Jaro has been a bilingual organization, and a song in solely Swedish or Finnish would be a highly unlikely commission from the team. The appearance of international players and coaches were key factors driving the need for an English translation (Kjell Strömsholm, personal communication 2013).

Historically, language has been an ideological issue as organized sports spread and teams were founded in Finland. The neighbouring city of Kokkola is home to the rival teams Gamlakarleby bollklubb (GBK) and Kokkolan Pallo-veikot (KPV). GBK was founded in 1924, while KPV was founded in 1930 by Finnish-speaking football players from GBK (Björkstrand i2014). The teams still have strong ties to the two language populations in Kokkola. Hence the official names of the team are in Swedish and Finnish respectively. KPV's song KPV humppa (see osurmaa 2008), one of the first recorded football songs in Finland, is only in Finnish. Comparatively, Gвк has a Finland-Swedish identity, despite lacking an original song in Swedish recorded for the team.

In Go Jaro go no geographical locations are mentioned, but in KPV's song the "sunti", the still-flowing strait in the centre of Kokkola, is mentioned and the chorus ends with the words "Kalahallin hiekasta noussut" ("Risen from the sand of Fish hall [ground]"). Sunti and Kalahalli are both well-known geographical places in Kokkola, although the latter is of more common knowledge in football culture since Kalahalli ground ("Fiskhallsplan" in Swedish) was a legendary sand football ground in Kokkola close to a fish market. Neither of these locations are explicitly connected to KPV or GBK, but this form of name dropping articulates community belonging and pride. From an outsider's perspective, they merely

\footnotetext{
3 In the 1960's there were several clubs in Pietarsaari which not only served the two different language groups, but were also positioned differently on the political map. When If Drott, which was seen as Swedish-speaking bourgeois club, dropped football from their repertoire of sports, Jaro was founded to fill the void, explicitly as a bilingual football team with no specific ties to social class formations. (FMI 445) Despite the fact that Jaro took its name due to a sponsorship from Ja-Ro (Jakobstads Rostfria ["Pietarsaari Stainless"]), a factory producing stainless steel pipes, Jaro should not be regarded as a "factory team".

4 The song's title on the record is KPV humppa foxsi but it is most commonly known as KPV humppa, Humppa is Finnish and can be described as a fast foxtrot with two beats per bar. The song was composed by Unto Jutila to lyrics by Heikki Nopanen, both authors with connections to Kokkola. The song and the recordings unknown b-side, Pallo-veikko marssi, was recorded in Helsinki in 1969 by the Erkki Valasteen Studio-Orkesteri. The sheet music is reproduced in Peltoniemi et al. (2010).
} 
localise the team with references to (perhaps unknown) physical places within the community. From the inside, referring to local places taps in to the concept of topophilia as it emphasises affective bonds, experienced as both an individual and as a part of a larger community. This territorialisation, with appropriation of local cultural capital at the expense of rivalling hegemonies, implies strive towards local superiority - "this city is ours".

$K P V$ humppa, recorded in the wake of the team's first national championship success is the team's unchallenged club song, and has been played during the team's entrance since its live debut in September 1969. According to Jaro's nowformer CEo Niklas Storbacka (i2012), Jaro has no official club song. But if you were to ask the fans, the English song Jeppis dynamite by local rock band Stormwing would spring to mind as representing Jaro. The song is mainly played at games but is frequently featured in YouTube videos produced by Jaro.

Stormwing also reflected upon the bilingual nature of both the Pietarsaari region and team, but the band took a different approach than the lyricists of Go Jaro go since English was the preferred language for the rock band (Wannäs i2013).

\begin{tabular}{|c|c|c|c|}
\hline Intro (8 bars) & Verse (8 bars) & Pre-chorus (8 bars) & Chorus (8 bars) \\
\hline $\begin{array}{c}\text { We are, we are all red and white } \\
\text { we're gonna win this game tonight } \\
\begin{array}{c}\text { We are, we are all red and white } \\
\text { we are the Jeppis Dynamite }\end{array}\end{array}$ & $\begin{array}{c}\text { We are the champions, number one } \\
\text { we're scoring goal in every town } \\
\text { we're taking three points one by one } \\
\text { we're the very best team around }\end{array}$ & $\begin{array}{c}\text { We are, we are all red and white } \\
\text { we're gonna win this game tonight } \\
\text { We are, we are all red and white } \\
\text { we are the Jeppis Dynamite }\end{array}$ & Jaro \\
\hline
\end{tabular}

Figure 1. A reduction of Jeppis dynamite's form and lyrics. врм $=145,4 / 4$ time.

What makes Jeppis dynamite a localised fight song is primarily the lyrics, which feature distinctive phrases linking it to the team; both the colours (red and white) expressed in the intro and the spelling out of the team's name in the chorus. The lyrics also articulate that there is a game that "we're gonna win". This addressing of the collective "we" also creates an implicit "them", the imagined rival who is seldom addressed by name in fight song lyrics.

What localises the song and makes it representative for the local community, while simultaneously nationally and globally uninteresting as mediaized music, is not the style of the song; the repetition of the title of the song, the words "Jeppis 
dynamite" is the absolute core of the piece. "Jeppis" is a commonplace term for the city of Pietarsaari, used in both Finnish and Swedish. "Jeppis" is commonly used by many Pietarsaari-based organizations as a reference to the city; for example, Jeppis Hockey Team (founded 1992) and Jeppis Floorball Club (founded 1996). The origin of the term "Jeppis" is unclear but as the city of Jakobstad (founded 1652) was named after Jacob De la Gardie, it has been suggested that it is derived from a nickname for Jacob. But Jeppis is more than a reference to a geographical place; Jeppis represents the unique bilingual space of Pietarsaari influenced by Swedish culture and language. By using the term "Jeppis" Stormwing avoids having to choose whether to use Pietarsaari or Jakobstad in the text, ultimately including both language groups in the song.

Finally, Jeppis dynamite also features distinctive unison sing-along phrases, inspired by crowd chanting. The most appealing part of the song is the chorus, in which the supporter can chant the team's name while clapping along to the $4 / 4$ beats (at approximately $145 \mathrm{bpm}$ ). The accentuated ride cymbal hits makes it suitable to clap along with. The chorus is also the part of the song most frequently used by Jaro, and is often featured in videos produced by the team. The double chorus (beginning at the drum fill at 2:14) is used as a goal song. A goal song is the song played via the stadium's PA-system when the home team scores. In this communal use, elements for the crowd to clap or sing along with are inevitable song features, as they facilitate the expression of a shared moment through sound. The "hey" and "go" shouts between the intro and the verse, on the other hand, mimic spontaneous individual shouts from the crowd.

Songs produced by supporters, just like chants, tend to include some profanity. Songs intended for public use by the team generally treat the opposition with greater respect; using uplifting words suitable for the whole family rather than disrespecting the opponents. According to musicologist Petri Tuovinen (2007: 21), if a song receives collective acceptance it, or parts of it, is sung by the fans at the stadium. In football culture this often powerful manifestation of local identity usually takes place during the teams' entrance. Collectively singing a song in English would perhaps seem odd to those who do not understand the song's foreign words, but generally in Finland the crowd claps more than it sings. Furthermore, Jeppis dynamite is not frequently sung by the (unofficial) supporter group, their repertoire is in Finnish and Swedish. Still, the group is commonly 
referred to as the (Jeppis) Dynamites, even though it's not a name that the group members use themselves.

Musicologist Keith Negus (1999: 29) proposed that the media contributes to the definition and boundaries of what falls within and without a genre of music, and that these genre conventions can shape what is produced and consumed by "providing incentives" and "imposing constraints upon musicians." Writing for a team and its community of fans does not provide the same kind of incentives, as the genre expectations are not circulated in the general media. Nevertheless, adding rhythmical elements or symbols with local significance is a genre expectation linked to the writing of team songs.

According to Porsfelt (2009: 196), there have emerged since mid-199os in Sweden a few bands that are more overtly linked to football clubs and their fans, so-called "supporter rock". The bands' entire repertoires consist of songs thematically linked to the teams and their fans. One could say that the teams' fans are the bands' audience, and outside of that context the bands would have little success in singing their repertoires of team-related songs. This is not the case with Stormwing, which was an established melodic hard rock band from Pietarsaari, and was quite successful in Japan. The problematic part for a band in writing a song for a specific team is not simply that the team's fans potentially are in conflict with the band's own fan base. On the one hand, aligning with a team might be good PR, since it potentially exposes the band to a new audience; on the other hand, it often involves subordinating the bands art and style to the stereotypical musical elements expected in fight songs. Making an effort for your local team can result in a sports song proving an odd duck in the band's oeuvre of mediaized songs. Therefore, it is also common that special ephemeral bands with local musicians are formed solely with the intention of making an effort; a recording for their team.

Stormwing does not regret making a song for Jaro, but acknowledges that this and other projects were seen as problematic (Wannäs i2013). The projects the band undertook offstage (Lundberg et al. 2003: 56) had an impact on the band's rock credibility, where Stormwing was an on stage actor with a repertoire of mediaized music. 


\section{The relocalisation of mediaized music into a new sporting context}

Some songs lend themselves easily to sports. Obvious examples, according to McGuinnes (2009: 186) are: Queen's We are the champions and Tina Turner's rendition of The best. One of the most popular songs related to sports is Queen's We will rock you, thanks to its distinctive stomp-stomp-clap motif which is used to activate the audience. The song's popularity in sporting contexts is also a result of the audience's competence to acknowledge the song's connection to sporting culture, thereby answering the "call" to participate in the completion of the movements suggested by the song. These are examples of songs that have been relocalised within a general sporting context through their perceived references to sporting culture, a connection strengthened and upheld locally through the repetition made possible by mediation technology.

I will argue in this chapter that mediaized music can be relocalised to different degrees; the strongest localised songs can become symbols of a team and representations of a locality to the same degree as unique songs written for local sports teams. This relocalisation of mediaized music does not include removing or adapting the music from the medium, but new meanings from the sporting context are assigned to the music as songs become part of new local practices. This means that songs spread through media, written for other purposes, can through use by teams and supporter communities gain new local meanings over time.

Musicologist Mark Katz (2010: 3) has pointed out that "recording influences musical activity" and that this influence manifests itself in human actions. This has been described by Lundberg et al (2003: 72) in terms of demediaization, where the music is localised by live musicians. This diversifying process can result in the arising of new musical variants. In the process of relocalisation I am arguing for here, this influence is manifested in new traditions of using a recording. As the recordings are not temporally rooted, this dislocalisation makes it possible for the songs to be localised in other cultural milieus.

Not all songs played in an arena environment gain new local meanings, although all acts of listening include some form of analysis of the music and its relation to context. As heard in a sports arena, mediaized music can be defined as what Jonathan Sterne calls foreground music (Sterne 2013: 126), music at- 
tending to aesthetic preferences by instrumentalizing taste for the creation of an environmental "feel." Its main structural purpose is to fill empty spaces in the soundscape with sounds and, in a sporting environment, to elicit crowd response (see Ahlsved 2014). Of the above mentioned songs, We will rock you and Another one bites the dust, as well as Gary Glitter's Rock and roll part 2 can be claimed to combine easily recognisable rhythmic elements or lyrics that reference sporting culture regardless of the artist's intentions.

These so-called sport rock anthems "have subsequently risen to iconic anthem status due largely to their significant exposure at sporting events and their perceived associations with sports culture" (McLeod 2006: 541). We learn about these ubiquitous songs through an enculturation process, by experiencing sporting culture and music. The Jock jam albums that compiled songs commonly heard at sporting events (McLeod 2006: 540-547) also benefited to the canonization of a repertoire of sport music by simply making them accessible ${ }^{5}$ on compilation albums. Today, access to music is not a problem and releases of compilations of localisable "sports music" have been complimented or replaced by other distribution channels, such as sports video games or by experiencing sports on television. Sports DJs, who act as gatekeepers to an arena's soundscape, can choose from an ever-growing amount of mediaized music. Video games are, as Tessler (2008: 19) points out, powerful tools for marketing new music, and for sports DJs the songs come with a built in connection to sporting culture. Tessler also points out that video games mimic how music is used in real stadiums.

Prior to the release of NHL 14, EA Sports wrote that "the NHL 14 soundtrack represents the kind of music fans love hearing in their team's home arena" (EA Sports 2013). This unveils a circle of commodification that feeds on the idea that DJs worldwide pick up the songs from the game's soundtrack and play them in local contexts. This can on one hand create a constantly changing local soundtrack, but also serves to homogenize the soundtracks of sports worldwide.

While mediaization and globalization are claimed to homogenize the world, which is visible through the formation of a standard repertoire at sporting events, it also can result in the paradoxical processes that Lundberg et al (2003: 408-425) described as "the play of opposites". Drawing on Giddens (1996), Lundberg et al.

5 Many writers have addressed these compilations, but few have commented on the fact that many of the songs are not in their original versions but have been reworked with additional crowd noise, foreseeing the most likely new use of the songs. 
exemplify how expressive forms, styles, and social relations have been removed from their original concrete contexts; thereby becoming accessible for use by people in other places, in other times. Disconnected from their original sources, they are pushed back into a new local context.

Not only does mediation allow music to be interpreted locally, but music can gain new meaning in new localities and communities. When I first heard Alte Kameraden (Vanhat toverit in Finnish) played at Jaro's games I did not understand its role in the context. The march had not been used since time immemorial, but was actually reinstated ${ }^{6}$ after being used at a friendly game against the British team Leyton Orient in July 2011, when Jaro was not obligated to play the Veikkausliiga sound logo during the entrance of the team. I later learned that it was requested by older fans and players, since the march was remembered as a popular march played before football games in Pietarsaari in the 1950s and 1960s (FMI 445). Unfortunately, teams tend to mostly focus on athletic developments when their historical accounts are published. These often undocumented traditions may strengthen an essentialist view that they have always been a part of the culture. Unveiling the traditions as socially constructed and perhaps even coincidental from the beginning, however, depicts how sports as an institution are not separated from society as a whole.

The widespread popularity of Alte Kameraden in Finnish society is emphasised by the fact that it is also used at a few other arenas in a 100 kilometre radius from Pietarsaari. At Vimpelin Veto's pesäpallo games in the small town of Vimpeli the march has most likely been played at the pesäpallo stadium "Saarikenttä" since the 1950s. At Vasa IFK's football games the tradition has been maintained since the ending of the Continuation War in September 1944 made it possible for football players to return to the pitch in Vaasa. The vifK players who had served together in the Finland-Swedish ${ }^{7}$ regiment IR 61 heard the march out at the front line, and thought it was suitable to play at the stadium when they resumed their football careers after the wars (Karlsson i2015). Aside from being popular music

6 After the season of 2015 Jaro was relegated to the second highest series in Finland. Many changes were made within the organisation, and for the season of 2016 the players were asked to choose their own entrance music. The chosen music was Heart of courage written by Two Steps from Hell, a music production company that focuses predominantly on music for movies and trailers. Their music has also been successful in various in sporting contexts. Without going in to a detailed analysis it can be said that a new localisation process has started at Jaro's games. 7 The Swedish-speaking minority of Finland is usually called the Finland-Swedes. 
at the time, the march, when played during entrances, also paid homage to those comrades who did not make it home. The title of the march echoes the IFK-motto "en gång kamrat, alltid kamrat" ("once a comrade, always a comrade"). After the Second World War Alte Kameraden was, according to Stolt (n.d), one of the few accepted military marches around the world, a so called "world march".

In Kokkola, the local rivals GBK and KPV adopted two different marches for their entrances. At GBK's home games The river Kwai march has been played since 1958 (Sundfors i2015) and is still played as the team walks on to the pitch. Before the 1969 premiere of their own song, KPV is said to have used Anchors aweigh (Björkstrand i2014). At a time when teams lacked the possibility to record own songs, they took their songs from an accessible and suitable mediaized repertoire representing marching to battle. Today, these pieces of music (Alte Kameraden and The river Kwai march) have been localised in their respective sporting communities, and despite the marches not being sung I agree with Tuovinen (2007: 12) that the game day ritual "creates a feeling of stability and uniformity".

What is central in the relocalisation process is not only the tension between local meanings and a global music repertoire, but also the tension between different localities and communities of fans. This is illustrated in a few paragraphs in Matti Wacklin's book Kirvesrinnat (2005: 196-197), where he describes how the two Tampere-based ice hockey teams Ilves and Tappara both originally had the intention of using Live is Life by the band Opus as a goal song, but Tappara made sure that it was played at their game first. Since most communities are imagined (Anderson 1992), collectively accepted symbols are powerful tools for the construction of a common "us", particularly when understood in the context of narratives of local or regional rivalry. Appropriating the same song would not promote uniqueness or support the construction of an imagined "us". Playing a localised song outside its new locality, for example playing a visiting teams song through the home team stadium's PA-system or at other valued locations, can result in topophilic conflicts. This can be viewed as provoking by fans (see Saxén 2016 or Kearns 2015) if the song is understood as to represent "them". I would like to suggest that it is a cultural competence to identify which songs and connected rituals represent whom, and on what level of competition. Nonrivalling teams may not even be aware of themselves being associated with the same representative symbols. 
In the context of discussing the portability of a sound recording Mark Katz refers to Walter Benjamin, who in his essay The work of art in the age of mechanical reproduction (1936) suggested that "[f]reed from its often exclusive and restrictive rituals art would be more accessible to the masses" (Katz 2010:18). Indeed Benjamin was correct regarding accessibility, but as Katz points out, reproductions, as in recordings, are not freed from rituals and traditions; rather, they create new ones. I will now illustrate how the relocalisation of recorded songs in the media saturated context of Finnish ice hockey has created new sonic rituals.

In a national advertising campaign, the advertising

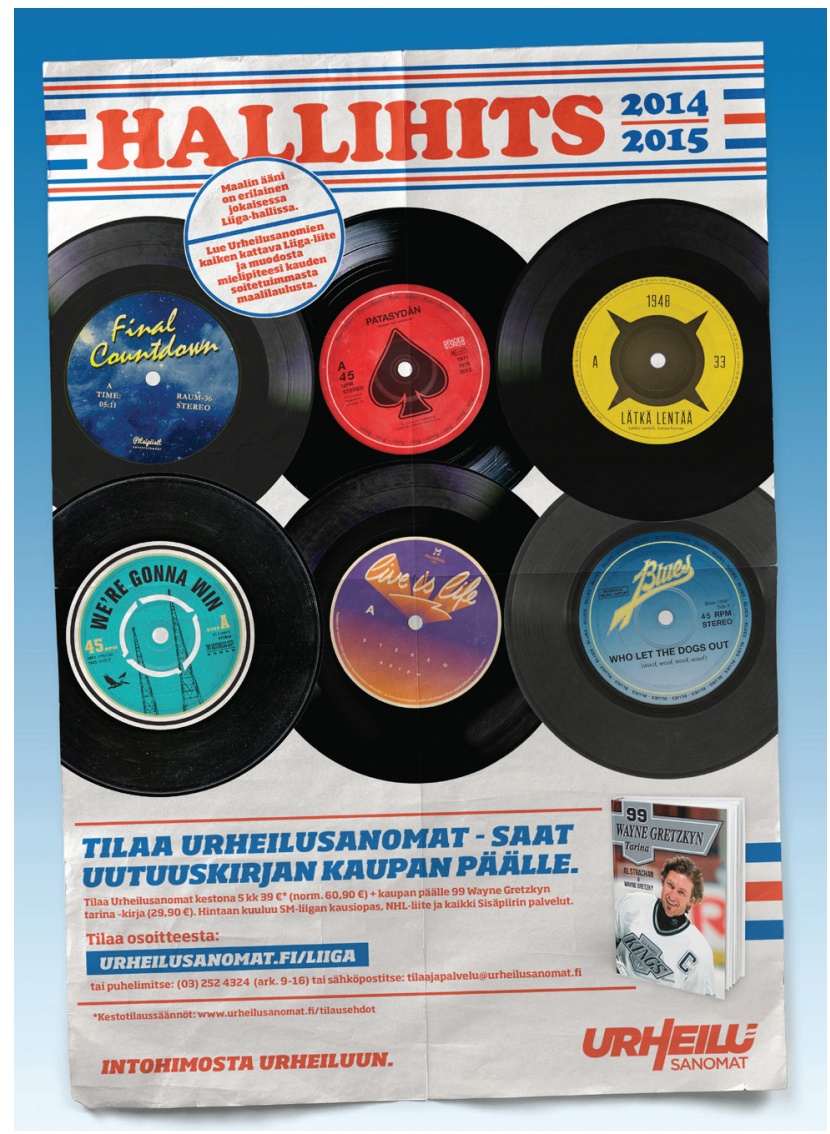

Figure 2. The advertisement with photo-shopped pictures of records, representing how the sound of goal is different in every Liiga-arena ("Maalin ääni on erilainen jokaisessa Liiga-hallissa"). agency Cassius neatly illustrated how "The sound of [a] goal is different in every Liiga ${ }^{8}$-arena." The ad acknowledged what is common knowledge among many hockey fans in Finland; which song is localised by whom. Interestingly, two of the songs in the ad, Patasydän ("Heart of Spades") and Lätkä lentää ("Flying puck") were actually written for the teams Ässät and SaiPa. In the ad, no distinction is made between the two locally produced songs and the four relocalised songs. The four relocalised songs, which are often used in sporting culture, are depicted as distinctive goal

8 "Liiga" is the name of the men's ice hockey league in Finland, and is the highest level of competition in Finland. 
songs for their respective teams: Final countdown (Lukko, Rauma), We're gonna wing (Pelicans, Lahti), Live is Life (Tappara, Tampere), and Who let the dogs out (Blues, Espoo). These songs are depicted as representing a team within in a certain ice hockey context. For the fans of the teams they can even be suggested to support the construction of team solidarity and local identity.

Over the years, Finnish ice hockey teams in particular have localised quite the repertoire of songs; adding to the narrative of Finnish ice hockey. One of the most known songs to have been adopted by a team in Finland is the Status Quo song Whatever you want. It first came to be associated with the Helsinki ice hockey team HIFK as part of a marketing campaign for the beer brand Koff in early 1990s. The songs Whatever you want and Let's work together by Canned Heat were featured in both television commercials and commercial "spots" played in the ice hall during HIFK games. The songs became so popular that the DJ continued to play the actual songs after the commercials stopped running. Today HIFK is still sponsored by the same brand but has no obligation to play the songs (Carlsson i2014). Nevertheless, the connection between the song and HIFK is so strong that it is now used for marketing and representing HIFK. When asking HIFK's marketing director about the teams' use of another popular HIFK song, Lynyrd Skynyrd's Red, white E blue, I was advised to not listen too closely to the music, since it is more about the sound and how it fits into the situation than what it actually means (Carlsson i2014). Locally interpreted connotations are encouraged while the original context of the song is not relevant.

The most obvious connection between HIFK and the Lynyrd Skynyrd song are the colours mentioned, which are the same as those on HIFK's jerseys. This overrides the more contradictory fact of HIFK's origins as a Swedish-speaking bourgeois sports club. Today, their audience is usually described as politically liberal or right-leaning, in opposition to Lynyrd Skynyrd and its redneck, working-class connotations. The listener is implied to localise the parts of the songs that are suitable to be interpreted as part of a new local context, disregarding other more contradictory aspects. This includes the appropriation of meanings into larger cultural contexts and narratives, moving the process closer to branding (see Edensor \& Millington 2008).

9 The Bryan Adams song We're gonna win is a fight song which includes loose lyrical references to sporting culture but is not linked to any locality. The lyrics give the listeners no clue to who the song is written for; it is practically up for grabs for any local sporting community worldwide. 
In Lynyrd Skynyrd's case the ideological contradiction is fascinating, since hockey in Helsinki has for a long time been divided in two. If HIFK is interpreted as "we" then the "other" team, those "plastic LA friends" Lynyrd Skynyrd mentions, might be understood as the rival team, Jokerit. Jokerit has in turn used the Foo Fighters' song popularly referred to as "Not like the others" (original title The pretender) as entrance music until the team moved to the Kontinental Hockey League (KHL). Since Jokerit is a much younger team its identity has often been interpreted in opposition to HIFK (Wickström 2012). It might therefore be understandable why once upon a time Jokerit adopted Bill Conti's Gonna fly now (from the film Rocky) as a goal song, which also meant localising the song and its underdog connotation in the narrative of Jokerit versus HIFK. When the schism between Jokerit and HIFK was at its most potent it, according to Jouni Munukka (2013), worked on three fronts: east/west (Helsinki), working-class/bourgeois, and Finnish/Swedish-ness. To promote the schism, which obviously sells tickets, the teams successfully localised songs that promoted certain aspects of the team's identity, narrative, and (hi)story. Jokerit promoted the "urban" with songs like Gerry Rafferty's hit Baker Street, and punk band Problems version of George de Godzinsky and Turo Kartto's Katupoikien laulu [1941]. The film tune Katupoikien laulu ("The street kids' song") tells the story of street kids on the east side of Helsinki and has also been sung by the band in the arena. The song I am by rappers Gracias and Noah Kin (Jokerit 2014), written for Jokerit's first season in the KHL league, is a continuation of this branding. On a more general level the teams have shaped distinctive musical profiles. HIFK uses stereotypical masculine rock music while Jokerit has adapted a more urban profile by also including hip-hop and electronic dance music.

\section{The demediaization of sports music through musical adaptation}

Musicologist Petri Tuovinen (2007: 16), who has written about football songs (chants) as constructors of a fan identity, has pointed out that terrace songs in general are an oral tradition and that songs travel from fan to fan. This oral culture of chanting is supported by an underlying culture of mediated music that feeds the supporter groups with familiar song and melodies. These songs written for other purposes have been spread through media, after which supporter com- 
munities have adapted the songs by rearranging them by, for example, adding new lyrics to them. In its new context and version the song is used to construct a local/team community.

In this context it is important to stress that the adaptations of the songs are primarily only sung, not recorded. Musicologist Ken McLeod, on the other hand, has discussed what he calls "hypermasculinized sports anthems" which are songs by gay icons such as Queen, The Village People, the Pet Shop Boys, and Gary Glitter (McLeod 2011: 119-120). While the connections to gay culture in some of these "sport rock anthems" are undeniable (see McLeod 2006), there is a need to underline that many of these songs are played in their mediaized format, while others are made famous after having been adopted and assigned new lyrics by fans around the world. There is a risk of exaggerating their (gay) connotations, and as I argue here, playing songs "from record" must not be interpreted as the same process as assigning new words to a familiar song.

This should not be confused either with the collective singing of songs like You'll never walk alone, localised by Liverpool FC (see Coslett 2008), or Idag är jag stark ("Today I am strong"), localised by Hammarby of Stockholm (see Cornell 2011). These are example of songs which seem to articulate community belonging without even being written for the team. These songs can of course be sung with or without the support of the original recording, but as the localisation is supported by (the use of a) a recording, and the words are not changed, I view these as two separate processes. The localisation and use of a recorded song can, as illustrated in the previous chapter, result in new rituals. Chanting popular melodies set to new words does not necessary relate, nor lead, to the communal use of the original recordings of the songs in question.

Indeed, fans can participate in the songs due to their widespread transnational popularity. This can also relate to musical features, as McLeod has stated that "all of these sports anthems feature a memorable easily sung chorus in which fans readily can participate" (McLeod 2006: 120). Nonetheless, you seldom hear fans sing Gary Glitter's Rock and roll part 2 without the support of the original song. Rather, it is, at least in a Finnish context, more common to hear supporter groups sing their own versions of $\mathrm{Na}$, na, hey, hey, kiss him goodbye or Go west than to hear the original song being played "from record". This distinction between using a song's mediaized version and the piece of music as adapted by chanting is also 
related to power. As globally imposed musical structures, to paraphrase DeNora (2000: 103), songs have been chosen to be played in their mediated format by a DJ through the stadiums PA-system. As demediaized by supporter groups, who have assigned the popular melody new lyrics, this is something done collectively on a grassroots level and it suggests another type of creative agency than the completion of coordinated bodily movements suggested in the music played by the DJ.

This creativity indicates a culture of adapting and reworking the actual piece of music into its new context, not only negotiating the meaning of the original lyrics in a stereotypically heterosexual sporting environment. But just as with digital mashups, it is possible to listen to the mixed elements separately. It can even be suggested that this is part of the fun.

For the song to be reworked into a new one, an important feature is the familiarity of the melody, as this allows many to join in and thus contribute to the fullness of sound vital for the territorialisation of spaces. The fact that it is often difficult to identify the original title of the melodies of many chants does not challenge this claim; rather it supports it, since mediated versions, detached from their original contexts, saturate our everyday life. Practically any melody will do when supporters demediaize them and assign them new meanings and functions. Allow me to illustrate:

For almost 30 years I have been a supporter of the football team Jaro. I do not go to many away games, but when I do, and if I go alone, I often go and stand with the supporter group. The group at away games is not big, but often consists of both Finnish and Swedish-speaking supporters. Just as there are bilingual references in the previously mentioned recorded songs, it is natural that the group has a repertoire of chants in both Finnish and Swedish. Although I might be a bit rusty in the beginning, I have no problem joining in the chants, as I am familiar with the songs from Jaro's home games and from being a part of the FF Jaro community for a very long time. The melodies are often familiar from football culture in general and new chants build on existing familiar melodies from everyday life. For example, the chorus of Go west has received the new lyrics "Jaro, tää matsi voitetaan," ("Jaro, we're going to win this game") which is repeated four times on the melodic structure of the chorus. All other parts of the song are left out. $\mathrm{Na}$, na, hey, hey, kiss him goodbye is simply repeated with lyrics "Sha-la-la-la-la-la-la, sha-la-la-la-la-la-la, oo-oo-oo, fF Jaro". 
Sometimes it can be difficult to remember the new lyrics, but if I so desired I could refresh my memory from the "song book" that the fans have shared in a supporters-only group on Facebook ${ }^{10}$. The texts are occasionally supported by links to original versions of the melodies, but most often with links to international supporter groups' versions of the same chant. If the melody is very common, such as When the Saints go marching in, only the song title is provided.

From whatever context or medium the music comes from, if it is the melody for a "new" composition or an adaption of an earlier version heard either live or from a recording, the music is "removed" from its medium and is given new lyrics. This is what I call demediaization, and differs from singing along to recorded songs. This reminds me of the process that popular music researcher Richard Middleton calls rearticulation (Middleton 1990: 16-19). He refers to an altered version of Amazing grace to illustrate how the song was rearticulated from the "bourgeois" to "working-class" by modification of the phrase structure. In fact, since fans learn from each other or via media, the songs are then even more detached from their original context. Class, race, gender, or social issues can still be implied, if the original sociocultural context of the song is known to the listener, but from the perspective of supporter groups these are not necessarily implied, since any melody, from opera to commercials, can become the carrier of a new message.

While doing fieldwork for his book Sing when you're winning (2006), Colin Irwin was initially inspired by the idea that "football crowds represent the one true surviving embodiment of an organic living folk tradition, i.e. a network of songs which evolved out of songs, sung by the people, adapted to meet the specific needs of geographical identity and seemingly created by spontaneous combustion, the unheralded originator remaining anonymous" (Irwin 2006: 13). In Irwin's book this idea turned into a celebration of football fans. The folk aspect of supporter culture is that the wandering melodies are not in focus, they merely serve as a foundation that is adapted to the singers' need and the story to be told.

On the other hand, soundscape researcher Meri Kytö (2011: 80) has pointed out that her research case, the Turkish supporter group Carsi, "flirts with mediated sound." This is an awareness of them being mediated, either by themselves in the form of videos posted on discussion forums, or being broadcasted on $\mathrm{TV}$. 
As Kolamo (2014: 17) points out, in the context of World Cup football, supporters acting as ideal fans are often mediated to the TV-audience. This, in conjunction with my own observations, sets the idea of terrace singing being an oral tradition into a new perspective.

Though I agree that supporter chants are in general conceived as an oral tradition, meaning that it is spread from peer to peer, the tradition does not exist in a non-mediated vacuum. The activity is part of a highly mediaized culture, a culture heavily influenced by mediation technology. When referring to Irwin's popular book it is also important to point out that it is written before the advent of social media and he does not discuss how fans communicate online or learn via forums or YouTube. Kytö, on the other hand, points out that the supporter group, which she refers to as an acoustic community, is supported by an electroacoustic community. Drawing on Truax's (2001) writings on electro-acoustic community, Kytö (2011: 88) points out that social media platforms serve as a medium for both sharing and learning about the acoustic atmosphere of a stadium. This "makes it possible for the fans to share experiences of belonging, reflecting and articulating their fan identity" (2011: 90). Mediation of chanting fans, as illustrated above, also means that one can listen to themselves as part of a community of some sort. With the introduction of social media this expanded, but is nothing totally new. In 1972, Liverpool fans were recorded as "The Kop Choir" (The Kop Choir, 1972). Though it could serve as a way of manifesting certain songs as Liverpool's, the compilation of field recordings was a way to capture the unique atmosphere at the games. Today, this can be done and communicated in real time with just a mobile phone connected to the internet.

Sheet music, which is music mediated in a written, "non-oral", "non-folk" format, makes it possible for a choir lead by a conductor to rehearse and learn music. ${ }^{11}$ A supporter group can also have their own "choir leader" (often called capo or amigo) but the oral nature of the culture is complemented by popular melodies and forums on the internet; not to mention social media where supporters can learn by experiencing, both visually and by ear, how songs have been adapted locally by fans around the world.

11 See Hill (2009) or Hellspong (2013) for some early examples of communal singing in football contexts. 


\section{The remediaization of sports music}

Songs that have gained new meanings locally by either being played or sung can be followed by a new mediaization process. According to Lundberg et al. (2003: 72) remediaization "occurs when the demediaized music is again conveyed via a medium." Lundberg et al.'s mediaization theories presuppose that the mediaized music is localised by local musicians as a part of a local music culture. In a sporting context this remediaization can be done by practically anyone with access to music technology, and this empowers fans today to create and rewrite culture and mediate it in its new form. This process includes the songs being rearranged with new lyrics or remediated as a remix or mashup of some sort. Of course, any song can be reworked many times, but what makes this process unique is that the remediaization process includes the possibility of interpreting, reflecting, and expressing localised symbols and meanings.

Today, mass media logic can be bypassed to a certain degree by what is called a DIY-attitude, meaning avoiding intermediation from commercial forces in the production process. In the wake of this democratization and its consequences on creativity, Lessig (2008: 28) has coined the terms "Read/Only culture" (RO) and "Read/Write culture" (RW); the former being a more passive form of consuming products from the content industry, while that latter hails digitalization and its creative potential for a new rise of amateur, folk, and popular culture.

I will now demonstrate how this remediaization process works in three different ways, all of which are in some way a continuation of processes described in the earlier chapters. All of the processes discussed previously can be followed by a new remediaization process and it is inspired by Lundberg et al.'s idea that mediaizational reworking is a continuation of the mediaization process. This was described by Lundberg et al. as a process that distanced the music even further from its local roots. While the remediaization of sports music can produce cultural products almost incomprehensible to those not belonging to the same community and culture, I will propose that remediaization is not stripping music from locally significant content: it facilitates the reinterpretation of community belonging by reworking localised symbols into new cultural products. This is something that needs not to be done in studios but can be done practically from home. 
First, as illustrated in the previous chapter, a song can be given local meanings. This process can be followed by remediaization, meaning that the demediaized song is recorded in its localised version. Remediaization makes it possible to "freeze" a localised version and distribute it. One melody that has been used for many supporter songs is Battle hymn of the republic (Irwin 2006, 108). This popular melody was also the foundation for the song Nyt Teps!! (see suursoo1979 2009), popularly called "Tepsi tekee kohta maalin" ("Tepsi [трs] is going to score soon"), which was recorded by a group called Seitsemän Seinähullua Veljestä for TPS, a Turku based team, in 1976. The march is originally believed to be a song called John Brown's body, for which Julia Ward Howe wrote new lyrics in 1861, and was eventually released as sheet music with the title Battle hymn of the republic. With that in mind, what Seitsemän Seinähullua Veljestä did was not that dissimilar to the actions of Julia Ward Howe; they adapted it to a new context with new lyrics. In both cases the song was made accessible with mediation technology.

TPS was far from the first to record the song. In 1976 the song had, according to Irwin (Irwin 2006: 108), already been made famous as a football chant by Tottenham Hotspur. It was released as a "singalong" in 1967, as well as a B-side to FA cup single Ossie's dream in 1981 (Seddon 1985: 397). It was first recorded by Scottish musician Hector Nicol as Glory, glory to the Hibees [Hibernian FC]. Leeds (1968) and Manchester United (1983) have their own recordings of this travelling, public domain melody as well.

Remediaization can also include rereleasing recorded songs that have become localised in their recorded version. Some teams have even released compilations of songs that have been localised by the team, without the songs being reworked for the record. These "team specific greatest hits", as McLeod (2011: 86) calls them, emerged in the wake of the Jock jams compilations. In Finland, songs commonly heard at HIFKs home arena have been released on the albums Rock it like a beast [2005] and This note's for you [2008]. Not only did these albums mediate popular songs heard at HIFK's games, they also promoted the HIFK brand and its connection to rock music. Since the localisation of Whatever you want and Let's work together, HIFK has essentially developed a distinct musical profile. This profile can also be understood in relation to HIFK's history of playing hard hitting hockey, referred to as "brand hockey" by the media in Finland. This image has 
its roots in the 1960s, when Canadian Carl Brewer led the team to success. Under Brewer's command the team started to play very physically. HIFK's DJs have developed a musical profile supporting this image and exclusiveness.

As McLeod (2011: 87) also notes, the popularity of team specific albums has waned, something I see as a consequence of technology serving to make music more mobile. Today, teams do not have to release albums touting local exclusivity; songs used by teams can be collected on, for example, publicly accessible Spotify playlists (see Pasi Örn n.d.). Although access to the songs is made easy by streaming services, this activity can be defined as read-only, the consumer can only consume culture by "reading" it (Lessig, 2008: 28-29). The fan is active by consuming (culture), participating primarily through consumption of (cultural) products.

In opposition to the fan as a sports consumer, adding to or recreating culture is a form of participatory culture, which I relate to the creativity behind the culture of chanting. Digitalization has democratized the supporters' ability to create and distribute culture. Just as any fan can write their own chant, the remediation of songs can today be done by the fans themselves, especially on YouTube. Building on Lessig's argument, the RW culture I am referring to is an amateurbased (amateur being French for "lover") fan activity. It is done for the love of the team, and can include the reworking and inclusion of songs that have penetrated the local sporting community and have thus already become a part of the culture. Most commonly, this RW culture is manifested in videos posted on YouTube. These videos often include reworking, meaning that the creator of the video has added something of their "own" to the video or perhaps even remixed songs connected to the team.

As mentioned previously, GBK of Kokkola has used The river Kwai march as their entrance music for a long time. This connection between GвK and the film tune has been mediaized by the Kokkola-based humour group Triio Peeråsetsi ("Trio potato sack"). Their tribute to GBK begins with a somewhat silly whistling of the popular melody from Colonel Bogey march (1914). ${ }^{12}$ But the band does not poke fun at marching culture, as early as the first phrase Trio Peeråsetsi sums up much of GBK's identity in Kokkola's distinctive Swedish dialect: "Skåd ny, ny komber G-B-K, ti har rööviit paitona på." ("Look here comes G-B-K, they wear 12 The Colonel Bogey march was reworked by Malcolm Arnold for the internationally successful film The bridge on the river Kwai (1958) as The river Kwai march. 
red and white [striped] shirts"). In those few words Trio Peeråsesti neatly depicts central aspects of GBK's identity; this song is about the Swedish-speaking team from Kokkola, the team which plays in red and white shirts. The inclusion of Colonel Bogey march as the song's foundation echoes the march's ubiquitous presence during matches and its symbolic role in the GвK community.

A staple piece of music in several Finnish sports arenas is the song Dirlanda, which was originally a traditional Greek folk song. It was translated to Finnish and recorded by the popular Finnish artist Kai Hyttinen in 1972, making it an example of how traditional music can be mediaized, demediated, and remediated in a context far removed from the original source of the music. The song was very popular in Finland in 1972-1973 (Nyman 2005: 140-141) and tells the story of a man travelling to Rhodos and falling for a beautiful woman. In a HC TPS context Dirlanda is the team's victory song, the song played when the team has won the home game. If you go to the Veikkausliiga team VPs's football games in Vaasa you will hear Dirlanda when the home team scores. At Vimpelin Veto's pesäpallo games the song belongs to the standard repertoire of older Finnish popular songs always played before the start of the actual game. YouTube user CasualPummi's looping of the "Classic Saarikenttä song" (CasualPummi 2013) to moving images of Vimpelin Veto's players at Saarikenttä remediates the creator's perceived link between the song and the team. These three different local meanings connected to Dirlanda need not be in conflict since the teams are not rivals (since they are competing in different sports), nor do they address the same community of people (also due to geographical reasons).

Another example is YouTube user 1897's video "HIFK:n legendaariset hallibiisit - Bad To The Bone" ("HIFK's legendary arena songs") that features HIFK's penalty song George Thorogood and the Destroyers' Bad to the Bone. Moving images and photos of HIFK's players playing hard have been added to the music. This video is not only a tribute to HIFK, it also remediates HIFK as being a hard playing team. Just like CasualPummi's video it not only mediates, as in distributes culture, it also recreates and interprets the culture. At the same time it also blurs the lines between consumers and creators of media content and those between professional and amateur culture.

Katz (2010: 20-21) suggests that "before the advent of recording, listening to music had always been a communal activity." The songs reworked and mediated 
on YouTube will perhaps never achieve more than solitary listening or viewing, and may perhaps never end up collectively listened to or sung at the stadium they reference, as teams tend to remediate media content only in line with their brand and image. Nonetheless, uploading songs and videos to YouTube is in line with Katz's claim, as it is an extension of the collectively heard and experienced. Modern, democratized technology empowers fans to reinterpret and remediate their identity, and as such is a tool for creating, upholding, and distributing culture.

\section{Conclusions}

The music heard at sporting events is very diverse, and my aim has been to analyse how music has been localised through different mediation and mediaization processes. I would like to suggest that through listening to the music at sports arenas we can learn a great deal about the sport, the team, its history, and its relation to the local community. But the music of the sports arena does not merely reflect, rather, it supports the construction of local identity as it becomes a part of local cultural practices. Mediated music aids the upholding of sonic rituals and symbols, but can also shape new ones since mediation technology allows both text and symbols to be distributed.

The music invites the crowd to participate. Through music one can be an active participant in the community, as manifested in, for example, communal singing or clapping, a way of bodily engaging with mediated music. Since the DJs serve as gatekeepers to the mediated soundscape of sports arenas they, and the organization, ultimately decide which mediated music is let in to the arena; unlike the demediaized music (chants) which supporters bring to the arena, or the various ways fans can remediaize music and culture on the Internet. I suspect that in the future the arena experience will become even more mediated, controlled, and commodified. This will have an impact on supporter agency and these tensions will raise new, interesting questions of both how and where members of a sporting community might articulate their identity. Not to mention which aspects of a team's or community's identity becomes remediated.

Of course most teams do not have enough own fight songs to fill all the empty slots in the soundscape. As long as organizers fear silence there will always be a 
need for new mediaized music to be played at games and the ubiquitous music of sporting events should always be examined in relation to its context. Localising primary mediaized music, as in music disseminated through media (both new and old) is contradictory: on one hand, many of the same songs are played around the world, which have shaped a repertoire of songs one can expect to hear at a sporting event. On the other hand, many of these canonized songs, which may seldom be encountered otherwise, are complemented by frequently played, ephemeral popular music. However, while the mediation of music may lead to homogenizing the soundtrack of sports, it may also open up for new local interpretation and adaptation of "old" music. 


\section{References}

\section{Archival sources}

SLS Archives/The Institute of Finland-Swedish Traditional Music, FMI 445

\section{Interviews}

Björkstrand, Olav (2014) Kokkola 29.6.2014. Interviewer: Kaj Ahlsved.

The interview is stored at sLs Archives/The Institute of Finland-Swedish Traditional Music, FMI 445

Carlsson, Roland (2014) Helsinki 7.2.2014. Interviewer: Kaj Ahlsved. The interview is in the researcher's possession.

Karlsson, Hans (2015). Vaasa 16.2.2015. Interviewer: Kaj Ahlsved.

The interview is stored at SLS Archives/The Institute of Finland-Swedish Traditional Music, FMI 445

Storbacka, Nicklas \& Wargh, Jimmy (2012) Pietarsaari 7.10.2012. Interviewer: Kaj Ahlsved. The interview is in the researcher's possession.

Sundfors, Bjarne (2015). Kokkola 17.2.2015. Interviewer: Kaj Ahlsved.

The interview is stored at SLS Archives/The Institute of Finland-Swedish Traditional Music, FMI 445

Wannäs, Sven (2013). E-mail interview. Interviewer: Kaj Ahlsved. Questions sent 14.8.2013, answers received 20.8.2013. The interview is in the researcher's possession.

\section{Video material}

1897 (2011). HIFK:n legendaariset hallibiisit - Bad To The Bone https:/ /www.youtube.com/ watch?v=fpCgu1EGcuQ (accessed 21.2.2016).

CasualPummi (2013). Vimpelin Veto superpesis-finaaleihin 2013. https://www.youtube.com/ watch?v=FlNtwTxm7qU (accessed 21.2.2016). 
FF Jaro (2013). Pampas | Go Go Jaro. http://www.youtube.com/watch?v=sufdfcgiceQ (accessed 21.2.2016).

gubbepotast (2012). Triio Peeråsetsi - GBK. https://www.youtube.com/watch?v= $\mathrm{U}_{5} \mathrm{C}_{2} \mathrm{~g} \mathrm{Xn}_{7 \mathrm{JM}} 8$ (accessed 21.2.2016).

Josef Krokvik (2010). Jaro - Jeppis Dynamite. https://www.youtube.com/watch?v=Vdeb4XpwfpA (accessed 21.2.2016).

osurmaa (2008). KPV-humppa. https:/ / www.youtube.com/watch?v=9q3EtP 5 JIhY (accessed 21.2.2016).

suurosoo1979 (2009). 7 seinähullua veljestä Nyt Teps!! jääkiekko eli Tepsi tekee kohta maalin. https:/ / www.youtube.com/watch?v=D-iRm1Zxrjk (accessed 21.2.2016).

\section{Spotify playlists}

Pasi Örn (n.d.) HIFK. https:/ / open.spotify.com/user/p\%C3\%B6rni/ playlist/2X58TuqC2wriTeFajuVozY [Spotify playlist] (accessed 21.2.2016).

The Kop Choir (1972). Liverpool Club's Own Football Sound. Hallmark Records: sHm794. The recording is accessible at: https:/ / open.spotify.com/artist/oeloonosjfujRlzbuPDRe7 (accessed 21.2.2016).

\section{Literature}

Ahlsved, Kaj (2013). "Det är hemmaplansfavör!" Strukturerna i tre sporters ljudlandskap studerade ur ett hi-fi/lo-fi-perspektiv. Etnomusikologian vuosikirja 25: 121-154.

Ahlsved, Kaj (2014). "Let's play hockey. Ishockeymusikens funktioner". Musiikki 44(1-2): 76-106. Ahlsved, Kaj (2015). "Marscher som fotbollskultur". Österbottens Tidning, 2.8.2015.

Anderson, Benedict (1992). Den föreställda gemenskapen. [Original Imagined Communities, revised and extended second edition 1991.] Göteborg: Daidalos.

Bale John (1993). Sport, Space and the City. [Reprint of First Edition]. Caldwell, New Jersey: The Blackburn Press.

Bale, John (2000). "The changing face of football: Stadiums and communities". Soccer E Society, 1:1, 91-101. 
Brusila, Johannes (2010). "'Maximum output for minimum input.' $1 \mathrm{G}_{3} \mathrm{~B}$ and the reterritorialization of a Finland-Swedish metal identity on the Internet." IASPM@Journal 1(2): $1-18$.

Bäck, Sören \& Sundqvist, Patrik (2002). Från Wilson till Westerlund. Jakobstad: Jakobmedia.

Cornell, Per 2011 "Aapo skrev Söders nationalsång". Södermalmsnytt, 18.11.2011 http:/ / www.stockholmdirekt.se/nyheter/aapo-skrev-soders-nationalsang/ Ldekkr!5OZYRmt45avwвеекрт93аA/ (accessed 13.02.2016)

Coslett, Paul. (2008). "You'll never walk alone". http:/ / www.bbc.co.uk/liverpool/content/ articles/2008/o6/og/youll_never_walk_alone_feature.shtml (accessed 29.1.2015).

Couldry, Nick \& Hepp, Andreas 2013. “Conceptualizing Mediatization: Contexts, Traditions, Arguments". Communication Theory 23:3, 191-202.

DeNora, Tia (2000). Music in everyday life. Cambridge: Cambridge University Press.

EA Sports (2013). "Listen to the NHL 14 Soundtrack" [6.9.2013]. http://www.easports.com/nhl/ news-updates-gameplay/article/nhl-14-soundtrack (accessed 12.9.2015).

Frandsen, Kirsten (2014). "Mediatization of sports". Mediatization of communication. Ed. Knut Lundby. Berlin: De Gruyter Mouton, 525-543.

Hellspong, Mats (2013). Stadion och Zinkensdamm. Stockholms idrottspublik under två sekel. Stockholm: Stockholmia förlag.

Hill, Jeffrey (2009). “War, remembrance and sport. 'Abide with me' and the FA Cup Final in the 1920s." Sporting Sounds. Relationships between sport and music. Eds. Anthony Bateman \& John Bale (eds.). London and New York: Routledge, 164-178.

Hjarvard, Stig (2013). The mediatization of culture and society. London: Routledge.

Jokerit (2014). I am - Gracias ja Noah Kin. Jokerit.com. http://www.jokerit.com/i-am-gracias-janoah-kin (accessed 21.9.2016).

Katz, Mark (2010). Capturing sound. How technology has changed music [revised edition]. Berkley and Los Angeles: University of California Press.

Kearns, Sean 2015. "You'll never walk alone at Old Trafford ahead of Super League Final." Metro. http:/ / metro.co.uk/2015/10/11/liverpool-superfan-dj-spoony-plays-youll-never-walkalone-at-old-trafford-ahead-of-super-league-final-5433443/ (accessed 2.2.2016).

Kolamo, Sami (2014). "Tunnekuvista tarinoita". Tekniikan Waiheita 4, 5-22.

Kytö, Meri (2011) “’We are the rebellious voice of the terraces, we are Carsi': constructing a football supporter group through sound". Soccer and Society, 12:1, 77-93.

Lessig, Lawrence (2008). Remix: making art and commerce strive in the hybrid economy. New York: Penguin Books. 
Lundberg, Dan \& Malm, Krister \& Ronström Owe (2003). Music Media Multiculture. Changing musicscapes [Online version: http://carkiv.musikverk.se/www/epublikationer/Lundberg Malm_Ronstrom_Music_Media_Multiculture.pdf].Stockholm: Svenskt visarkiv.

Lundby, Knut (2014). "Mediatization of communication". Mediatization of communication. Ed. Knut Lundby. Berlin: De Gruyter Mouton, 3-35.

Malm, Krister \& Wallis, Roger (1992). Media Policy and Music Activity, London and New York: Routledge.

McGuinnes, Mike (2009) "'Friday Night and the Gates are Low': popular music and its relationship(s) to sport." Sporting Sounds. Relationships between sport and music. Eds. Anthony Bateman \& John Bale (eds.). London and New York: Routledge, 179-192.

McLeod, Ken (2006). "'We are the Champions': Masculinities, Sports and Popular Culture”. Popular Music and Society, 29:5, december 2006, 531-547.

McLeod, Ken (2011). We are the Champions: The Politics of Sports and Popular Music. Farnham: Ashgate.

Middleton, Richard (1990). Studying Popular Music. Milton Keynes: Open University Press.

Munukka, Jouni (2013). "Asuvatko HIFK:n kannattajat lännessä ja Jokerien idässä?". Helsingin Sanomat, 23.2.2013. http:/ / www.hs.fi/urheilu/a1361514231256 (accessed 19.7.2016).

Negus, Keith (1999). Music genres and corporate cultures. London and New York: Routledge. Nyman, Jake (2005). Suomi soi. 4. Suuri suomalainen listakirja. Helsinki: Tammi.

Peltoniemi, Olli \& Peltoniemi, Jukka \& Kentala, Voitto \& Kuusela Pekka (eds) (2010). Kokkolan Pallo-Veikot 80 vuotta. Kokkola: KPV Juniorit ry.

Porsfelt, Dan (2009). "Supporter rock in Sweden: locality, resistance and irony at play". Sporting Sounds. Relationships between sport and music. Ed. Anthony Bateman \& John Bale. London and New York: Routledge, 193-209.

Saxen, Filip (2016) "Inlägget: Dags att sätta de äkta fansen på förstaplats". Hufvudstadsbladet ,18.2.2016. https:/ / www.hbl.fi/artikel/inlagget-dags-att-satta-de-aktafansen-pa-forstaplats/ (accessed 18.2.2016).

Seddon, Peter J. (1995). A football compendium. A Comprehensive Guide to the Literature of Association Football. Wetherby: The British Library.

Sterne, Jonathan (2013). "The Non-aggressive Music Deterrent". Ubiquitous Musics. Ed. Marta García Quiñones \& Anahid Kassabian \& Elena Boschi. Farnham: Ashgate, 121-138.

Stokes, Martin 2007. On musical cosmopolitanism. The Macalester International Roundtable 2007. Paper 3. [http:/ /digitalcommons.macalester.edu/intlrdtable/3] (accessed. 21.2.2016). 
Stolt, Lars C (n.d.) "Alte KAMERADEN, Carl Teike" http:/ / www.militarmusiksamfundet.com/ $\mathrm{dev} /$ index.php?page=show_article\&id=altekameraden (accessed 21.2.2016).

Tessler, Holly 2008. "The new mTv? Electronic Arts and 'playing' music". From Pac-Man to Pop Music. Ed. Karen Collins. Aldershot: Ashgate.

Tuan, Yi-Fu (1974). Topophilia. Englewood Cliffs: Prentice-Hall.

Tuovinen, Petri (2007) "Fanilaulut jalkapallokannattajien identiteetin rakentajana". Musiikki, $3 / 2007 \cdot 7-32$.

Turino, Thomas (2003). "Are We Global Yet? Globalist Discourse, Cultural Formations and the Study of Zimbabwean Popular Music." British Journal of Ethnomusicology, 12:2, 51-79. Wacklin, Matti (2005). Kirvesrinnat. Tapparan tarina. Tampere: Tamhockey.

Wallis, Roger \& Malm, Krister (1984). Big sounds from small people. The music industry in small countries. London: Constable.

Wickström, Mika (2012). HIFK-Jokerit. Taistelu Helsingin herruudesta. Helsinki: Tammi 